\title{
Development and Validation of Teacher Computer Self Efficacy Scale
}

\author{
S.Thangarasu ${ }^{1}$ S. Vincent De Paul ${ }^{2}$ \\ ${ }^{1}$ Lecturer, Planning \& Management Branch, District Institute of Education \& Training, Pudukkottai 622004 \\ ${ }^{2}$ Reader, State Council of Educational Research and Training, DPI Campus, College Road, Chennai, 600006, \\ Tamilnadu, India,
}

\section{Introduction}

Self-efficacy is a strong and consistent predictor of grade point average and expectations of academic success. Self- efficacy which refers to a person's judgment of own capabilities to organize and execute courses of action required to attain designated type of performance has also been found to be a major contributor to an individual's academic achievement (Bandura, 1986). From the studies of Pajares, (1996); Pajares \& Miller, (1997); Pajares \& Valliant, (1997), Covington, (2000), Robins \& Bear, (2001) it can be concluded that self efficacy plays a critical role in educational achievement. Schrand (2008) suggests the use of technology in education has several benefits for motivating students. Schrand further states that technology can facilitate more active student learning in the classroom, and appeal to multiple intelligences, and different learning styles.

In the modern communication era, many computer based technologies have entered into the teaching learning processes. The review of researchers in integration of these technologies reveals that effective ways of integrating these technologies depends mostly on the computer efficacy of teachers and the learners. The concept of Computer efficacy is the extension of the efficacy concept of Bandura.

Adapted from the self-efficacy concept, computer self-efficacy is the extent of an individual's perceived ability to use a computer. Delcourt \& Kinzie (1993) defined computer self-efficacy as a measure of how confident computer users are with their ability to understand, use, and apply computer knowledge and skills. The authors found that individuals who have high computer self-efficacy will feel competent in using different computer hardware and software. However, a low computer self-efficacy leads to the belief that individuals will encounter difficulty in using computers hardware and software.

Ertmer, Addison, Lane, Ross \& Woods (1999) suggested that educators with higher computer selfefficacy are likely to be more enthusiastic to use technology in their classrooms than those with lower levels of self-efficacy. They concluded that educators' personal beliefs with regard to their computer proficiency are the main factors in determining whether or not they will use computers in teaching and learning. The researchers also noted that many newly graduated teachers are more proficient at using computers than their more experienced colleagues. These skills, however, often could not be used because routine teaching obligations often hindered their efforts. Furthermore, a study by Czaja et al. (2006) among 1,204 adults (men = 454, female =750) ranging in age from 18 to 91 years found that computer self-efficacy was an important predictor of general use of technology and that people with lower self-efficacy are less likely to use technology in general.

\section{Measuring Computer Self-Efficacy}

Many instruments have been developed to measure computer self-efficacy. There are measurement tools developed by Hill, Smith, \& Mann (1987), Murphy, Coover, \& Owen (1989), Delcourt \& Kinzie (1993), Busch (1995), Compeau \& Higgins (1995), and Durndell, Haag, \& Laithwaite (2000). Several computer selfefficacy measures were found in the literature, but no single measure is universally accepted.

The first computer self-efficacy scale was introduced by Murphy, Coover and Owen (1989) with 32 items to measure an individual's perceptions of his capability regarding specific computer related knowledge and skills. The instrument was administered to 414 individuals that included graduate students, adult vocational students, and professional nurses learning to use computers. The authors used the 5 point Likert-type format $(1=$ very little confidence to $5=$ quite a lot of confidence), and participating respondents were asked to indicate the degree to which they felt. The authors performed factor analysis with an oblique rotation which produced three factors concerning computer skills (a) beginning level, (b) conceptual (advanced), and (c) mainframe. The reported Cronbach's alpha for the three empirically derived factors was $0.97,0.96$, and 0.92 , respectively.

Harrison and Rainer (1992) replicated the factor structure found by Murphy, Coover and Owen (1989) in their study to measure respondent perceptions regarding specific computer-related knowledge and skills. The instrument was administered to 693 university personnel who fully completed the survey. The participant group derived from four broad university job categories: (a) clerical, (b) technical, (c) faculty, and (d) administrative. 
The Cronbach's alpha coefficients for the three subscales on the computer self-efficacy skill scale were 0.97 on the beginning, 0.95 on the advanced, and 0.98 on the mainframe.

Torkzadeh and Koufteros (1994) used the 32 item scale with slight modification from Harrison and Rainer (1992). The authors removed two items from the original scale and opted to alter a Likert scale ( $1=$ strongly disagree to $5=$ strongly agree). The items removed were (a) using the computer to analyze number data, and (b) learning advanced skills within a specific program (software). The authors administered the instrument to 224 business undergraduates at a large State university in the Midwest of the United States at the beginning and at the end of an introductory computer course. The authors examined factorial validity of this instrument with an oblique rotation and recommended a four-factor skill solution which was identified as (a) beginning, (b) mainframe, (c) advanced, and (d) file and software. The authors reported reliability for each factor as $0.94,0.96,0.90$ and 0.91 respectively.

Compeau and Higgins (1995) developed and tested a measure of computer self-efficacy, using a survey in an effort to understand the impact of self-efficacy on individual reactions to computer technology in business and industry. Bandura's (1997) social cognitive theory was employed to create a model for testing the effects of computer self-efficacy. The researchers' 10 item computer self-efficacy measure was designed to be task focused and to incorporate elements of task difficulty including computer use, anxiety, affect, outcome expectations, and organizational support, as well as encouragement by others. This survey was administered to 1,020 managers and professionals including insurance adjusters, financial analysts, researchers, consultants, and accountants. Their research concluded that computer self-efficacy influences individuals' use of the computer and learning to use computers, and empirically verified a strong link between self-efficacy and individual reactions to computing technology. They also found that computer self-efficacy exerted significant influence on (a) individuals' expectations of the outcomes of using computers, (b) emotional reactions to computers, and (c) their actual computer use. In this research, the authors discovered that individuals with high self-efficacy used more computers, enjoyed using them, and experienced less computer-related anxiety.

Durndell and Haagb (2002) adopted a computer self-efficacy instrument that had been modified by Torkzadeh and Koufteros (1994) and made further changes to it in their study. The researchers removed all three statements that were related to mainframe as they reasoned that technology through the emphasis on standalone machines has rendered these skills obsolete for most persons. The authors later added back the two statements that were originally used by Murphy, Coover and Owen (1989) (a) using the computer to analyze number data, and (b) learning advanced skills within specific program (software). This instrument was translated into the Romanian language and was administered to 200 students at a university in Romania at the end of the participants first academic year. A year later, the English version of Durndell and Haagb scale was administered to students in a university in Scotland under the same conditions and time of the academic year. A total of 148 students $($ male $=43$, female $=105)$ participated in the study. In Scotland, the reported Cronbach's alpha coefficient was 0.96 and in Romania was 0.95 . These alpha coefficients indicated that the instrument used was reliable.

There are many notable instruments used to measure computer self-efficacy. Lee and Bobko (1994) found that asking the respondents to rate their self-efficacy strengths and weaknesses were the most common measures of self-efficacy. Karsten and Roth (1998) recommended that researchers select the computer selfefficacy instrument whose items most closely reflect the skills they wish to measure and that the skills be clearly identified.

\section{Need and Significance of the Study}

In the modern information and communication technological world the technological inputs provided by the child also has an impact in the achievement of the child. Teachers should have adequate level of integrating technological inputs into the teaching learning process. Since most of the modern technological inputs are based on the computer the teacher should have adequate level using or adopting computer efficacy. The review of related literature reveals that no much study has been carried out in measuring computer self efficacy of teachers in general and elementary schools in particular. Hence the researchers made an attempt to develop and validate the Teacher Computer Self Efficacy Scale.

\section{Development of Teacher Computer Self Efficacy Scale (TCSES)}

The items for the development of Teacher Computer Self Efficacy Scale (TCSES) were drawn from various sources like personal interviews conducted with teachers and discussion with experts in the field of educational technology and the review of related literature.

\subsection{Factors of Teacher Computer Self Efficacy Scale (TCSES)}

Items selected for Teacher Computer Self Efficacy Scale (TCSES) consisted of the following factors. 


\section{General Operation of Computer}

Teacher should have the efficacy in handling the Computer. He / She should know the fundamental operations of computer. Teacher should have efficacy in selecting, installing application software for effective classroom transaction. He / She should have the skill of copying, saving and editing the files in the computer so that he/she can adopt the computer for his classroom activities.

\section{Word Processing}

The teacher has to keep the documents for his/her classroom. He / She should know how to create a word document in the computer. He / She should know how to edit the word document by incorporating border, tables, objects, etc., formatting, using find /replace commands etc. Therefore teacher should have efficacy in handling the word processor for effective classroom transaction.

\section{Spreadsheets / Excel}

To understand students' progress teacher has to handle some data. Handling data in a computer saves much time to the teacher and also serves as a ready reckoner. Teacher should know how to enter data in spreadsheet and do simple mathematical calculations and drawing graphs and editing excel spreadsheets and files. Hence teacher should have efficacy of handling Excel Spreadsheets.

\section{PowerPoint Presentation}

Teaching should maximize the learning among the learners. To make teaching lively teacher should use appropriate PowerPoint presentation. It demands the skill of creation of slide, insertion of slide, editing of slides by inserting objects, tables, graphs, pictures etc., formatting the presentation, doing animation etc,. Hence teacher should have efficacy of preparing and applying PowerPoint Presentation for effective classroom transaction

\section{Internet}

Today online education has entered into the field of education. Anyone can access his area of study by the concept anywhere at any time. In the present technologically advanced era, teacher should know how to do some fundamentals operations related to internet such as creation of e-mail id, browsing of mail, sending mails to others with attachment and non attachments, browsing the relevant material without compromising time management, helping the students to use the search engine effectively etc., Hence teacher should have efficacy of handling Internet for his/her classroom transaction in general and online education in particular.

\section{Classroom Process}

Computer Assisted Teaching, Leaning, and Management have entered in the teaching leaning process. Managing the process makes the system more successful. Teacher should know how to use the Word, Excel, PowerPoint, Internet etc effectively in the classroom. Hence teacher should have efficacy of managing the computer aided learning process.

\subsection{Pooling of Items}

Keeping in view the above six factors, 170 items in total, 30 items under General Computer Operations, 25 items under Word Processing, 35 items under Spreadsheet / Excel, 30 items under PowerPoint, 25 items under using Internet / Web and 25 items under Teaching- Learning through Computer were pooled.

\subsection{Scrutiny and Evaluation of Items}

These pooled items were subjected to a more careful scrutiny. The items which seemed to overlap with one another were critically examined. An item conveying the objectives of the tool was retained and care was taken to maintain the language of the items simple and meaningful. This process of scrutiny and evaluation finally yielded 165 items.

\subsection{Evaluation of Items by Expert}

In order to establish whether a given item really belongs to that particular factor, the items were arranged in a random order and subjected to expert scrutiny. The experts were drawn from the field of Primary / Elementary Education (faculty from DIET and University Department). In order to facilitate the experts judging the items, they were presented with operational definition of factors. The experts were asked to indicate whether items were clearly stated and easily understood by the teachers and to suggest necessary modification if any. The items of the scale had two categories of responses, viz., Yes and No This process finally yielded 163 items. 


\subsection{Administration of Items}

The Teacher Computer Self Efficacy Scale (TCSES) thus developed was given to a sample of 100 teacher trainees and 100 teachers of Pudukkottai District. The investigator explained the objectives of the study to the trainees and teachers and asked them to rate appropriately in one of the two response categories against each item. Trainees and teachers were asked to mark every item without omitting anyone. No time limit was imposed. The filled in TCSESs were scored in the order of ' 1 ', ' 0 ' for the responses, yes and no. Scores obtained by each individual were summed up and used for further analysis.

\subsection{Item Analysis}

In order to select the valid items for the final study, $t$ value was calculated using the formula suggested by Edward (1957).

where

$$
t=\frac{X_{H}-X_{L}}{\frac{S_{H}^{2}}{N}+\frac{S_{L}^{2}}{N}}
$$

$\mathrm{X}_{\mathrm{H}}$ is the mean score of the upper group on a given statement

$\mathrm{X}_{\mathrm{L}}$ is the mean score of the lower group on a given statement

$\mathrm{S}_{\mathrm{H}}{ }^{2}$ is the variance of distribution of response of upper group to the statement

$\mathrm{S}_{\mathrm{L}}{ }^{2}$ is the variance of distribution of response of lower group to the statement

$\mathrm{N}$ is the number of subjects in the upper group / lower group.

The obtained $t$ values for

Table .1

' $t$ ' values of items in Teacher Computer Self Efficacy Scale (TCSES)

\begin{tabular}{|c|c|c|c|c|c|}
\hline Item Number & $\mathrm{t}$ & $\begin{array}{c}\text { Positively / } \\
\text { Negatively worded }\end{array}$ & Item Number & $\mathrm{t}$ & $\begin{array}{c}\text { Positively / } \\
\text { Negatively worded }\end{array}$ \\
\hline 1 & 7.968 & $\mathrm{~N}$ & 84 & 17.134 & $\mathrm{P}$ \\
\hline 2 & 8.592 & $\mathrm{P}$ & 85 & 12.944 & $\mathrm{~N}$ \\
\hline 3 & 9.647 & $\mathrm{P}$ & 86 & 25.361 & $\mathrm{~N}$ \\
\hline 4 & 4.135 & $\mathrm{~N}$ & 87 & 22.252 & $\mathrm{P}$ \\
\hline 5 & 6.057 & $\mathrm{~N}$ & 88 & 13.715 & $\mathrm{P}$ \\
\hline 6 & 8.529 & $\mathrm{P}$ & 89 & 22.252 & $\mathrm{~N}$ \\
\hline 7 & 7.683 & $\mathrm{P}$ & 90 & 20.243 & $\mathrm{P}$ \\
\hline 8 & 6.466 & $\mathrm{~N}$ & 91 & 13.110 & $\mathrm{~N}$ \\
\hline 9 & 10.736 & $P$ & 92 & 10.324 & $\mathrm{P}$ \\
\hline 10 & 8.226 & $\mathrm{~N}$ & 93 & 14.471 & $\mathrm{~N}$ \\
\hline 11 & 9.411 & $\mathrm{P}$ & 94 & 12.944 & $\mathrm{P}$ \\
\hline 12 & 11.249 & $\mathrm{P}$ & 95 & 14.471 & $\mathrm{P}$ \\
\hline 13 & 8.354 & $\mathrm{~N}$ & 96 & 13.559 & $\mathrm{~N}$ \\
\hline 14 & 7.582 & $\mathrm{~N}$ & 97 & 25.361 & $\mathrm{P}$ \\
\hline 15 & 5.978 & $\mathrm{P}$ & 98 & 18.529 & $\mathrm{P}$ \\
\hline 16 & 7.056 & $\mathrm{P}$ & 99 & 20.042 & $\mathrm{~N}$ \\
\hline 17 & 4.724 & $\mathrm{P}$ & 100 & 19.976 & $\mathrm{~N}$ \\
\hline 18 & 16.279 & $\mathrm{P}$ & 101 & 25.239 & $\mathrm{P}$ \\
\hline 19 & 12.830 & $\mathrm{~N}$ & 102 & 29.632 & $\mathrm{P}$ \\
\hline 20 & 8.874 & $\mathrm{P}$ & 103 & 37.121 & $\mathrm{P}$ \\
\hline 21 & 8.893 & $\mathrm{~N}$ & 104 & 15.530 & $\mathrm{~N}$ \\
\hline 22 & 11.639 & $\mathrm{P}$ & 105 & 29.632 & $\mathrm{P}$ \\
\hline 23 & 6.686 & $\mathrm{~N}$ & 106 & 15.600 & $\mathrm{~N}$ \\
\hline 24 & 5.676 & $\mathrm{~N}$ & 107 & 36.770 & $\mathrm{P}$ \\
\hline 25 & 10.562 & $\mathrm{P}$ & 108 & 29.632 & $\mathrm{~N}$ \\
\hline 26 & 11.739 & $\mathrm{P}$ & 109 & 18.529 & $\mathrm{P}$ \\
\hline 27 & 8.452 & $\mathrm{P}$ & 110 & 15.530 & $\mathrm{~N}$ \\
\hline 28 & 13.110 & $\mathrm{~N}$ & 111 & 20.243 & $\mathrm{P}$ \\
\hline 29 & 9.881 & $\mathrm{P}$ & 112 & 25.239 & $\mathrm{P}$ \\
\hline 30 & 13.875 & $\mathrm{P}$ & 113 & 19.976 & $\mathrm{P}$ \\
\hline 31 & 16.786 & $\mathrm{~N}$ & 114 & 18.864 & $\mathrm{~N}$ \\
\hline 32 & 11.468 & $\mathrm{~N}$ & 115 & 25.239 & $\mathrm{~N}$ \\
\hline 33 & 8.131 & $\mathrm{P}$ & 116 & 53.000 & $\mathrm{P}$ \\
\hline 34 & 17.134 & $\mathrm{P}$ & 117 & 29.632 & $\mathrm{P}$ \\
\hline 35 & 11.810 & $\mathrm{~N}$ & 118 & 25.361 & $\mathrm{~N}$ \\
\hline 36 & 11.739 & $\mathrm{P}$ & 119 & 22.790 & $\mathrm{P}$ \\
\hline 37 & 8.780 & $\mathrm{P}$ & 120 & 16.744 & $\mathrm{~N}$ \\
\hline 38 & 13.559 & $\mathrm{~N}$ & 121 & 25.239 & $\mathrm{P}$ \\
\hline 39 & 22.252 & $\mathrm{~N}$ & 122 & 22.427 & $\mathrm{P}$ \\
\hline
\end{tabular}


Development and Validation of Teacher Computer Self Efficacy Scale

\begin{tabular}{|c|c|c|c|c|c|}
\hline Item Number & $\mathrm{t}$ & $\begin{array}{c}\text { Positively / } \\
\text { Negatively worded }\end{array}$ & Item Number & $\mathrm{t}$ & $\begin{array}{c}\text { Positively / } \\
\text { Negatively worded }\end{array}$ \\
\hline 40 & 8.145 & $\mathrm{~N}$ & 123 & 16.914 & $\mathrm{~N}$ \\
\hline 41 & 22.790 & $\mathrm{P}$ & 124 & 22.252 & $\mathrm{~N}$ \\
\hline 42 & 13.620 & $\mathrm{P}$ & 125 & 13.620 & $\mathrm{P}$ \\
\hline 43 & 10.848 & $\mathrm{~N}$ & 126 & 29.632 & $\mathrm{P}$ \\
\hline 44 & 10.740 & $\mathrm{P}$ & 127 & 25.739 & $\mathrm{~N}$ \\
\hline 45 & 14.968 & $\mathrm{P}$ & 128 & 19.976 & $\mathrm{P}$ \\
\hline 46 & 15.966 & $\mathrm{~N}$ & 129 & 19.976 & $\mathrm{~N}$ \\
\hline 47 & 13.620 & $\mathrm{P}$ & 130 & 25.239 & $\mathrm{P}$ \\
\hline 48 & 13.332 & $\mathrm{~N}$ & 131 & 37.121 & $\mathrm{~N}$ \\
\hline 49 & 12.017 & $\mathrm{P}$ & 132 & 37.121 & $\mathrm{P}$ \\
\hline 50 & 16.914 & $\mathrm{P}$ & 133 & 37.121 & $\mathrm{P}$ \\
\hline 51 & 12.944 & $\mathrm{~N}$ & 134 & 20.243 & $\mathrm{~N}$ \\
\hline 52 & 18.212 & $\mathrm{P}$ & 135 & 53.000 & $\mathrm{P}$ \\
\hline 53 & 8.893 & $\mathrm{~N}$ & 136 & 20.042 & $\mathrm{~N}$ \\
\hline 54 & 12.017 & $\mathrm{~N}$ & 137 & 17.134 & $\mathrm{P}$ \\
\hline 55 & 37.121 & $\mathrm{P}$ & 138 & 20.591 & $\mathrm{P}$ \\
\hline 56 & 13.620 & $\mathrm{P}$ & 139 & 18.212 & $\mathrm{~N}$ \\
\hline 57 & 12.944 & $\mathrm{~N}$ & 140 & 18.529 & $\mathrm{~N}$ \\
\hline 58 & 13.715 & $\mathrm{P}$ & 141 & 25.361 & $\mathrm{P}$ \\
\hline 59 & 14.099 & $\mathrm{P}$ & 142 & 20.591 & $\mathrm{P}$ \\
\hline 60 & 16.786 & $\mathrm{~N}$ & 143 & 25.239 & $\mathrm{~N}$ \\
\hline 61 & 14.744 & $\mathrm{P}$ & 144 & 25.361 & $\mathrm{P}$ \\
\hline 62 & 18.316 & $\mathrm{~N}$ & 145 & 13.875 & $\mathrm{~N}$ \\
\hline 63 & 12.306 & $\mathrm{P}$ & 146 & 13.332 & $\mathrm{P}$ \\
\hline 64 & 11.739 & $\mathrm{P}$ & 147 & 30.017 & $\mathrm{~N}$ \\
\hline 65 & 18.316 & $\mathrm{~N}$ & 148 & 29.632 & $\mathrm{P}$ \\
\hline 66 & 13.620 & $\mathrm{P}$ & 149 & 22.427 & $\mathrm{~N}$ \\
\hline 67 & 13.715 & $\mathrm{P}$ & 150 & 15.600 & $\mathrm{P}$ \\
\hline 68 & 12.944 & $\mathrm{~N}$ & 151 & 18.316 & $\mathrm{P}$ \\
\hline 69 & 16.786 & $\mathrm{~N}$ & 152 & 12.056 & $\mathrm{~N}$ \\
\hline 70 & 13.715 & $\mathrm{P}$ & 153 & 22.252 & $P$ \\
\hline 71 & 18.864 & $\mathrm{P}$ & 154 & 25.361 & $\mathrm{P}$ \\
\hline 72 & 12.944 & $\mathrm{~N}$ & 155 & 18.212 & $\mathrm{~N}$ \\
\hline 73 & 11.511 & $\mathrm{P}$ & 156 & 12.944 & $\mathrm{~N}$ \\
\hline 74 & 17.457 & $\mathrm{~N}$ & 157 & 29.632 & $\mathrm{~N}$ \\
\hline 75 & 18.212 & $\mathrm{~N}$ & 158 & 36.770 & $P$ \\
\hline 76 & 53.000 & $\mathrm{P}$ & 159 & 18.212 & $\mathrm{P}$ \\
\hline 77 & 29.632 & $\mathrm{P}$ & 160 & 19.976 & $\mathrm{~N}$ \\
\hline 78 & 30.017 & $\mathrm{P}$ & 161 & 16.914 & $\mathrm{~N}$ \\
\hline 79 & 18.316 & $\mathrm{~N}$ & 162 & 15.530 & $\mathrm{P}$ \\
\hline 80 & 20.042 & $\mathrm{P}$ & 163 & 18.316 & $\mathrm{P}$ \\
\hline 81 & 13.110 & $\mathrm{~N}$ & & & \\
\hline 82 & 36.770 & $\mathrm{P}$ & & & \\
\hline 83 & 20.243 & $\mathrm{P}$ & & & \\
\hline
\end{tabular}

The ' $t$ ' value of the Teacher Computer Self Efficacy Scale (TCSES) ranged from 4.135 to 53.000. All the items were significant at 0.001 levels. Hence six items having greater ' $t$ ' values in each dimensions were selected for final scale. Following the criteria stated above, altogether 66 items out of 163 items were selected. Since the factors of TCSES are well defined the six dimensions of Teacher Computer Self Efficacy viz., General Computer Efficacy, Word Processing Efficacy, Spreadsheets / Excel Efficacy, PowerPoint Presentation Efficacy, Internet Efficacy and Computer in Classroom Process Efficacy are considered as it is, in the final scale.

\subsection{Reliability of Teacher Computer Self Efficacy Scale (TCSES)}

The reliability of Teacher Computer Self Efficacy Scale (TCSES) was established by calculating Cronbach alpha and inter- observer method. An inter-rater reliability analysis using the Kappa statistic was performed to determine consistency among raters. The calculated value is 0.85 that shows substantial agreement (Landis \& Koch, 1977). The Cronbach alpha value for each factor and total are as shown in the Table .1. 
Table .2

Reliability Coefficient of Teacher Computer Self Efficacy Scale (TCSES)

\begin{tabular}{|c|c|c|c|c|}
\hline $\begin{array}{l}\text { S. } \\
\text { No. }\end{array}$ & Name of the Factor & Item Numbers & $\begin{array}{l}\text { No. of } \\
\text { items }\end{array}$ & $\begin{array}{l}\text { Cronbach alpha } \\
\text { value }\end{array}$ \\
\hline 1. & General Computer Efficacy & $\begin{array}{l}1^{*}, 2 *, 9,18,21,28,35,47^{*}, 53,58^{*}, 65 \\
*\end{array}$ & 11 & 0.9738 \\
\hline 2. & Word Processing Efficacy & $\begin{array}{l}2,7,16^{*}, 23,26^{*}, 36,41^{*}, 48^{*} \\
51,59,64^{*}\end{array}$ & 11 & 0.9729 \\
\hline 3. & Spreadsheets / Excel Efficacy & $\begin{array}{l}3^{*}, 8,17,22^{*}, 25^{*}, 32,42,44, \\
52,55,63 *\end{array}$ & 11 & 0.9832 \\
\hline 4. & PowerPoint Presentation Efficacy & $\begin{array}{l}12,15^{*}, 24^{*}, 27^{*}, 31,39,40^{*}, 43,50^{*}, 6 \\
0,62^{*}\end{array}$ & 11 & 0.9843 \\
\hline 5. & Internet Efficacy & $\begin{array}{l}6,11^{*}, 14^{*}, 19,30^{*}, 34,38^{*} \\
46,49^{*}, 57,66^{*}\end{array}$ & 11 & 0.9720 \\
\hline 6. & $\begin{array}{l}\text { Computer in Classroom Process } \\
\text { Efficacy }\end{array}$ & $\begin{array}{l}5,10^{*}, 13^{*}, 20,29,33^{*}, 37^{*} \\
45,54^{*}, 56,61 *\end{array}$ & 11 & 0.9768 \\
\hline & All factors combined & & 66 & 0.9959 \\
\hline
\end{tabular}

* Negative items

Thus from the two coefficients, it may be concluded that the Teacher Computer Self Efficacy Scale (TCSES) is highly reliable.

\subsection{Validity of Teacher Computer Self Efficacy Scale (TCSES)}

The validity of the tool was established by circulating the tool to the expert in the field. The intrinsic validity was established by taking the square root of the reliability coefficient. The reliability coefficient is 0.9959 and hence the intrinsic validity is 0.9979 . Thus, it may be concluded that the TCSES is highly valid.

\section{Conclusion}

The final version of the Teacher Computer Self Efficacy Scale (TCSES) was designed with the 66 valid items. This scale is a Likert Type five point scale (Strongly Agree. Agree, Undecided, Disagree, and Strongly Disagree). In the case of positive items, the scoring is ' 5 ', '4', '3', '2', and ' 1 ' for Strongly Agree. Agree, Undecided, Disagree, and Strongly Disagree respectively. In the case of negative items, the scoring is ' 5 ', ' 4 ', '3', '2', and '1' for Strongly Disagree. Disagree, Undecided, Agree, and Strongly Agree respectively. The maximum possible score is 330 and the minimum is 66. The highest score indicates the existence of high Computer Self Efficacy among trainees.

\section{References}

[1] Bandura, A. (1986). Social foundations of thought and action: A social cognitive theory. Englewood Cliffs, NJ: Prentice-Hall.

[2] Pajares, F. (1996). Self - Efficacy Beliefs in Academic Setting. Review of education Research, 66 (4), p. 543-578.

[3] Pajares, F. and Miller, M. D. (1997). Mathematics Self-Efficacy and Mathematics Outcomes: The Need for Specificity of Assessment. Journal of Counseling Psychology, 42, p. 190-198.

[4] Pajares, F. and Valiante, G. (1997). Difference of Self-Efficacy on Elementary Students Writing. The Journal of Education Research. 90 (6), p. 353-361.

[5] Covington, M. V. (2000). Goal Theory, Motivation and Students achievement: An Integrated Review. Annual Review of Psychology, 51, p. 171-200.

[6] Robins, R. W. and Beer, J. S. (2001). Positive Illusions about the Self: Short-term Benefits and Long-Term Costs. Journal of Personality and Social Psychology, 80, p. 340-352.

[7] Schrand, T. (2008). 'Tapping Into Active Learning and Multiple Intelligences with Interactive Multimedia: A Low-Threshold Classroom Approach.' College Teaching, 56 (2) pp. 78-84. Retrieved July 21, 2008, from http://proquest.umi.com

[8] Delcourt Marcia, A. B. and Kinzie Mable, B. (1993). Computer Technologies in Teacher Education: The Measurement of Attitudes and Self-Efficacy. Journal of Research and Development in Education, 27 (1), p. 35-41.

[9] Ertmer, P. A., Addison, P., Lane, M., Ross, S. and Woods, D. (1999). Examining Teachers' beliefs about the role of technology in the elementary classroom. Journal of Research on Computing in Education. 32 (1), p. 54-72.

[10] Czaja, S. J., Charness, N., Fisk, A. D., Hertzog, C., Nair, S. N. and Rogers, W. A. (2006). Factors predicting the use of technology: Findings from the center for Research and Education on Aging and Technology Enhancement. Psychology and Aging, 21 (2) p. 333-352.

[11] Hill, T., Smith, N. D. and Mann, M. F. (1987). Role of Efficacy Expectations in predicting the decisions to use advanced technologies: The case of Computer. Journal of Applied Psychology. 72 (2), p. 307-313.

[12] Murphy, C.A., Coover, D. and Owen, S. V. (1989). Development and Validation of the Computer Self Efficacy Scale. Educational and Psychological Measurement. 49, p. 893-899.

[13] Busch, T. (1995). Gender differences in Self Efficacy and attitude toward Computers. Journal of Educational Computing Research, 12 (2), p 147-158 
[14] Compeau, D. R. and Higgins, C.A. (1995). Computer Self Efficacy: Development of measure and initial test. Management Information System Quarterly 19 (2), p. 189-211

[15] Durndell Alan., Haag Zsolt and Laithwaite Heather (2000). Computer Self Efficacy and Gender: A cross cultural study of Scotland and Romania. Personality and Individual Differences. 28, p. 1037-1044.

[16] Harrison, A., Rainer, R., Hochwarter, W. and Thompson, K. (1992). Testing the self- efficacy performance linkage of socialcognitive theory. The Journal of Social Psychology, 137 (1), p. 79-87.

[17] Torkzadeh, G. and Koufteros, X. (1994). Factorial Validity of a Computer Self Efficacy Scale and the impact of computer training. Educational and Psychological Measurement. 54 (3), p. 813-821.

[18] Bandura, A. (1997). Self-efficacy: The exercise of control. New York: W.H. Freeman.

[19] Durndell Alan and Haagb Zsolt (2002). Computer self efficacy, computer anxiety, attitudes towards the Internet and reported experience with the Internet, by gender, in an East European sample. Computers in Human Behavior, 18, p. 521-535.

[20] Lee, C. and Bobko, P. (1994). Self Efficacy Beliefs: Comparisons of Five Measures. Journal of Applied Psychology. 79 (3), p. 3.

[21] Karsten, R. and Roth, R. M. (1998). The relationship of Computer Experience and Computer Self Efficacy to performance in introductory computer literacy courses. Journal of Research on Computing in Education. 31 (1), p. 14-23. 